\title{
Digestibility of Dry Matter and Organic Matter of Fermented Sago Pulp on Local Sheep Male Weaning
}

\author{
A A Sembiring, T H Wahyuni, N D Hanafi, A H Daulay, Hasnudi \\ Animal Production Program, Faculty of Agriculture, Universitas Sumatera Utara, \\ Medan 20155 \\ E-mail: ariesembiring90@gmail.com
}

\begin{abstract}
This study aims to analyze the digestibility of dry matter and organic matter of fermented sago pulp alternative feed on local sheep male weaning. Research conducted at Karang Rejo village farm, Stabat district, Langkat. This study in Maret 2016-Juny 2017. The design used was completely randomized design (CRD), with four treatments five replications. Each repeat consists of one local sheep male weaning with the average of body weight $8-10$ $\mathrm{kg}$. The treatment consisted of P1(consentrat with $50 \%$ sago pulp without fermented + forage), P2 (consentrat with 60\% sago pulp without fermented + forage), P3 (consentrat with 50\% sago pulp fermented + forage), and P4 (consentrat with $60 \%$ sago pulp fermented + forage). The variable were studied dry matter consumption, organic matter consumption, dry matter digestibility and organic matter digestibility.

Results of analysis of variance show that the utilization of fermented sago pulp waste had highly significantly different effect $(\mathrm{P}<0,01)$ on dry matter consumption of treatment $\mathrm{P} 1, \mathrm{P} 2$, P3 and P4 is 486,38; 548,68; 604,69; and 671,11 (gr/head/day), and organic matter consumption is 469,$34 ; 525,22 ; 582,42$ and $644,40(\mathrm{gr} / \mathrm{head} / \mathrm{day})$. And average of dry matter digestibility waste not significantly different effect $(\mathrm{P}>0,05)$ on value dry matter digestibility of treatment P1, P2, P3 and P4 is 79,04; 79,23; 78,59 and 78,23 (\%), average of organic matter digestibility is 81,$66 ; 81,43 ; 80,79$ and $80,27(\%)$. Increasing use of fermented pulp sago increases the value of dry matter consumption and organic matter consumption in local sheep feed. Conclusions of fermented sago pulp can not to increase dry matter digestibility and organic matter digestibility, but fermented and non-fermented sago pulp can be given to sheep male weaning up to $60 \%$, because the digestibility value of the two ingredients is above $70 \%$.
\end{abstract}

\section{Introduction}

A stretch of wild sago in Indonesia has an area of 1.6 million hectares, of the extents in the year 2005 can be produced 15 million tonnes of sago as each stem produces $200 \mathrm{~kg}$ sago. The spread of the plant sago in Indonesia are Irian Jaya 1,406,469 hectares, Maluku 41,949 hectares, Sulawesi 45,540 hectacres, Kalimantan 2,795 hectares, Jawa Barat 292 hectacres, and Sumatra 31,872 hectares. Pulp sago (ela sago) obtained at sago flour processing, [1] in processing of sago flour obtained sago flour and pulp by comparison 1:6. Based on the proportion the number of sago dregs produced as 245,000 tons/day. Therefore alternative use of sago pulp is used as animal feed.

Sago pulp is a solid waste produced by processing sago starch which is available quite a lot throughout the year, cheap and easy to obtain. In the processing of sago obtained $18.5 \%$ sago starch and $81.5 \%$ sago pulp. Sago pulp has excellent prospects, if it gets the right treatment. Sago pulp potentially large enough as an energy source feed with ingredient BETN $77.12 \%$, but the low crude protein is $2.70 \%$ and other ingredient crude fat $0.97 \%$, crude fiber $16.56 \%$, and ash $4.65 \%$. One of to increase the nutrient content of pulp sago by fermentation.Fermentation in principle is enable the growth and metabolism of microorganisms required so that a new product with a different raw material. Fermentation is going to do is use microbes as using the MOD. 
Sago pulp fermented can increase the nutrient content of sago pulp, one of them is protein. Protein is the basic constituent materials of all tissues of the body are formed, for example muscles, blood cells for growth and development. Granting of protein livestock have to do with sustainability through the ration for growth, the turnover of the cells and other products. If a given protein is not enough then it will cause the growth of cattle is not normal. Waste processing sago waste categories include wet (wet by-products) because it still contains $75-80 \%$ water content, so it can be broken quickly if not immediately processed. Through drying treatment (made of flour) and used as mixtures of feed sheep is an alternative technology, so that these products can be utilized more efficiently. Remember sago pulp has high potential as an ingredient of fodder of ruminants including sheep, then to do research on the utilization of the flour mixture as sago pulp feed the sheep.

Digestibility of a feed material is very important because it can be used to determine the value or quality of a feed material. The dry ingredients of a feed material consisting of nitrogen compounds, carbohydrat, fat and vitamin. Digestibility of a feed material is affected by several factors, including the chemical composition of the feed material, the composition of the ration, ration physical form, feeding rate and factor that comes from the livestock itself.

\section{Materials and Methods}

This research was conducted at the Karang Rejo village farm, Stabat district, Langkat. This study lasts for 4 months starting from Maret 2016 to Juny 2017.

The material used is 20 local sheep with weight $8-10 \mathrm{~kg}$. Feed ingredients of field grass, sago pulp, Aspergillus nigger, consentrat, drugs such as permentyhl 5\%, kalbazen, terramycin, vitamin Bcomplex, water, and rodalon. The tool used is individual cages, feed and drinking water area, scales, lamp, plastic burlap, brooms, shovels, buckets, raffia, plastic drums, thermometers, and stationery.

The research method used was complete randomized design (RAL) with 4 treatments and 5 replications. The treatment under study is as follows:

$\mathrm{P} 1=$ Consentrat with $50 \%$ without fermented sago pulp + forage

$\mathrm{P} 2=$ Consentrat with $60 \%$ without fermented sago pulp + forage

$\mathrm{P} 3=$ Consentrat with $50 \%$ fermented sago pulp + forage

$\mathrm{P} 4=$ Consentrat with $60 \%$ fermented sago pulp + forage

Obseved variabels were dry matter consumption, organic matter consumption, dry matter digestibility, and organic matter digestibility.

\subsection{Dry Matter Digestibility (KcBK)}

Dry matter digestibility can be measured by calculating by the formula :

Digestibility BK $=\frac{\text { konsumsi BK (gram)-BKfeses (gram) }}{\text { konsumsi BK (gram) }} \times 100 \%$

\subsection{Organic Matter Digestibility (KcBO)}

Organic matter digestibility caan be measured by calculating by the formula :

Digestibility BO $=\frac{\text { konsumsi BO }(\mathrm{gram})-\mathrm{BO} \text { feses }(\mathrm{gram})}{\text { konsumsi BO }(\mathrm{gram})} \times 100 \%$

\section{Results and discussion}

The results showed a very significant difference $(\mathrm{P}<0,01)$ on dry matter consumption and organic matter consumption. And average of dry matter digestibility waste not significantly difference $(\mathrm{P}>0,05)$ on dry matter digestibility and organic matter digestibility presented in the table below.

Table1. Parameters : dry matter consumption, organic matter consumption, dry matter digestibility, and organic matter digestibility

\begin{tabular}{ccccc}
\hline \multirow{4}{*}{ Trearment } & \multicolumn{4}{c}{ Parameter } \\
\cline { 2 - 5 } & Dry Matter & Organic Matter & Dry Matter & Organic Matter \\
& Consumption & Consumption & Digestibility & Digestibility \\
& $(\mathrm{gram} / \mathrm{h}$ had/day $)$ & $(\mathrm{gram} / \mathrm{head} /$ day $)$ & $(\%)$ & $(\%)$ \\
\hline
\end{tabular}




\begin{tabular}{lllll}
\hline P1 & $486,38^{\mathrm{d}}$ & $469,34^{\mathrm{d}}$ & $79,04^{\mathrm{tn}}$ & $81,66^{\mathrm{tn}}$ \\
P2 & $548,68^{\mathrm{c}}$ & $525,22^{\mathrm{c}}$ & $79,23^{\text {tn }}$ & $81,43^{\text {tn }}$ \\
P3 & $604,69^{\mathrm{b}}$ & $582,42^{\mathrm{b}}$ & $78,59^{\text {tn }}$ & $80,79^{\text {tn }}$ \\
P4 & $671,11^{\mathrm{a}}$ & $644,40^{\mathrm{a}}$ & $78,23^{\text {tn }}$ & $80,27^{\text {tn }}$ \\
\hline
\end{tabular}

Description : Different superscripts in the same column show a very significant difference effect $(\mathrm{P}<0,01)$, and different superscripts in the same column show not significant difference effect $(\mathrm{P}>0,05)$.

\subsection{Dry Matter Consumption}

From the data of dry matter consumption in the above table shows the highest average on treatment $\mathrm{P} 4$ (consentrat with $60 \%$ fermented sago pulp + forage) that is equal to $671,11 \mathrm{gram} / \mathrm{head} /$ day and lowest rate at treatment P1 (consentrat with $50 \%$ without fermented sago pulp + forage) that is equal to 486,38 $\mathrm{grams} / \mathrm{head} /$ day.

Based on the analysis of the variety of consumption of dry ingredients of feed during the study gave a very significant different effect $(\mathrm{P}<0,01)$. Further Duncan test results showed that the average consumption of dry matter feed between $\mathrm{P} 1, \mathrm{P} 2, \mathrm{P} 3$ and $\mathrm{P} 4$ was very significant $(\mathrm{P}<0,01)$.

It can be seen that the average consumption of dry feed ingredients during the study had a very significant different effect $(\mathrm{P}<0.01)$. The existence of a very significant difference in the consumption of dry matter is influenced by several factors such as the health condition of the animal, the level of feed digestibility and quality of feed so that it results in a very significant difference in the consumption of dry feed ingredients. This is in accordance with statement of [2] which states that the consumption of dry matter depends on many factors, including the digestibility of dry feed ingredients, the energy content of feed metabolism and the crude fiber content of a feed. Dry matter digestibility is measured to determine the amount of food absorbed by the body which is carried out through analysis of the amount of dry matter, both in rations and in feces. The difference in the amount of dry matter consumed and the amount excreted is the dry matter digestibility. This is also in accordance with the statement of [3] which states that the level of differences in consumption is influenced by several factors including livestock factors (body weight, age, feed digestibility, feed quality and palatability).

\subsection{Organic Matter Consumption}

From the data of organic matter consumption in the above table shows the highest average on treatment P4 (consentrat with 60\% fermented sago pulp + forage) that is equal to 644,40 $\mathrm{gram} / \mathrm{head} /$ day and lowest rate at treatment P1 (Consentrat with $50 \%$ without fermented sago pulp + forage) that is equal to $469,34 \mathrm{grams} / \mathrm{head} /$ day.

Based on the analysis of the variety of consumption of organic ingredients of feed during the study gave a very significant different effect $(\mathrm{P}<0,01)$. Further Duncan test results showed that the average consumption of organic matter feed between $\mathrm{P} 1, \mathrm{P} 2, \mathrm{P} 3$ and $\mathrm{P} 4$ was very significant $(\mathrm{P}<0,01)$. It can be seen that the average consumption of organic feed ingredients during the study had a very significant different effect $(\mathrm{P}<0.01)$. Different results are very real, adjusted for the results of dry matter consumption. This is due to the consumption of organic feed ingredients in line with the consumption of dry feed ingredients because dry ingredients consist of organic matter and ash so that the amount of consumption of organic matter is directly proportional to the amount of dry matter consumption. This is consistent with the statement of [4] which states that organic matter is part of dry matter, so that when dry matter increases it will increase organic matter, and vice versa. In addition, according to [5] that the high and low consumption of feed is influenced by external factors (environment) and internal factors (the condition of the livestock itself) which includes environmental temperature, palatability, taste, physiological status (age, sex, body condition), concentration nutrient, feed form, body weight, and production.

\subsection{Dry Matter Digestibility}

Dry matter digestibility is absorbed by the substance body through analysis of the amount of dry matter, both in rations and in feces. The difference between the amount of dry matter consumed and the amount of excretion divided by the amount of dry matter consumed is dry matter digestibility. From the data of dry matter digestibility in the above table shows the highest average on treatment P2 (consentrat with 60\% without fermented sago pulp + forage) that is equal to 79,23\% and lowest rate at treatment $\mathrm{P} 4$ (consentrat with $60 \%$ fermented sago pulp + forage) that is equal to $78,23 \%$. 
Based on the analysis of the variety of digestibility of dry ingredients of feed during the study gave not significant different effect $(\mathrm{P}>0,05)$. Further Duncan test results showed that the average digestiility of dry matter feed between $\mathrm{P} 1, \mathrm{P} 2, \mathrm{P} 3$ and $\mathrm{P} 4$ was not significant $(\mathrm{P}>0,05)$.

It can be seen that the average digestibility of dry matter of feed during the study gave a different effect which was not significant $(\mathrm{P}>0.05)$. This is because each animal has different abilities in digesting rations, resulting in differences in digestibility. This is consistent with [6] which states that the digestibility of dry matter is influenced by the protein content of the feed, because each protein source has different degradation solubility and resistance. Each type of ruminant animal has rumen microbes with different abilities in degrading rations, resulting in differences in digestibility. Consumption with digestibility affects each other. If consumption increases, feed digestibility will increase, and vice versa. The dry matter digestibility of feed which is very different between treatments illustrates how much the amount of dry matter feed can be used by sheep. This is consistent with the statement of [7], which states that the value of feed digestibility reflects the level of nutrient value that can be utilized by the body of livestock used for production both basic life needs and weight gain. The higher feed digestibility value means that the feed treatment that can be used by livestock is higher. Feed digestibility is affected by the composition of feed, amount of feed given, form of feed and crude fiber content in feed given to livestock.

\subsection{Organic Matter Digestibility}

The digestibility of organic materials in the digestive tract of livestock includes the digestibility of feed substances in the form of components of organic materials such as carbohydrates, proteins, fats and vitamins. The difference in the amount of organic matter consumed and the amounts expressed divided by the amount of organic matter consumed is the digestibility of organic matter.

From the data of dry matter digestibility in the above table shows the highest average on treatment P1 (consentrat with 50\% without fermented sago pulp + forage) that is equal to $81,66 \%$ and lowest rate at treatment $\mathrm{P} 4$ (consentrat with $60 \%$ fermented sago pulp + forage) that is equal to $80,27 \%$.

Based on the analysis of the variety of digestibility of organic ingredients of feed during the study gave not significant different effect $(\mathrm{P}>0,05)$. Further Duncan test results showed that the average digestiility of organic matter feed between P1, P2, P3 and P4 was not significant $(\mathrm{P}>0,05)$.

It can be seen that the average digestibility of feed organic matter during the study gives a different effect which is not significant $(\mathrm{P}>0.05)$. The results are a very significant difference from the digestibility of organic matter in line with the digestibility of dry matter because organic matter is part of dry matter so that when dry matter increases it will increase organic matter as well as vice versa. This is consistent with the statement of [4], which states that organic matter is part of dry matter, so that when dry matter increases it will increase organic matter, and vice versa. Therefore, this will also apply to the digestibility value, if the dry matter digestibility (KcBK) increases, the organic matter digestibility $(\mathrm{KcBO})$ will also increase. Therefore, factors that influence the high and low dry matter digestibility $(\mathrm{KcBK})$ will also influence the high and low organic matter digestibility $(\mathrm{KcBO})$ rations. The digestibility value of organic matter ranged from $55.62 \%$ to $57.06 \%$ higher than the value of dry matter digestibility which ranged from $55.62 \%$ to $57.06 \%$ due to organic matter not containing ash so that the material without ash content was relatively more easy to digest. This is in accordance with the statement of [4] which states that dry matter in feed still contains ash, while organic material does not contain ash, so the material without ash content is relatively easier to digest. Ash content slows or inhibits dry matter of ration dry matter.

\section{Conclusions}

Fermented of sago pulp can not to increase dry matter digestibility and organic matter digestibility, but fermented and non-fermented sago pulp can be given to sheep male weaning up to $60 \%$, because the digestibility value of the two ingredients is above $70 \%$.

\section{References :}

[1] Rumalatu. 1981. Potensi dan Pemanfaatan Sagu. Kanisius. Yogyakarta.

[2] Ranjhan, S. K. 1980. Animal Nutrition In The Tropics. Vikas Publishing House P and Ltd. New Delhi. 
[3] Parakkasi. A. 1995. Ilmu Gizi dan Makanan Ternak Ruminan. Jakarta. UI-Press.

[4] Fathul, F dan S. Wajizah. 2010. Penambahan mikromineral Mn dan Cu dalam ransum terhadap aktivitas biofermentasi rumen domba secara in vitro. JITV 15 (1) : 9-15.

[5] Kartadisastra, H. R. 1997. Penyediaan dan Pengelolaan Pakan Ternak Ruminansia. Kanisius. Yogyakarta.

[6] Basri. 2014. Kecernaan bahan kering dan bahan organik ransum komplit dengan kandungan protein berbeda pada kambing marica jantan. Skripsi. Fakultas Peternakan. Universitas Hasanuddin. Makassar.

[7] Tillman, A. D., H. Hartadi, S. Reksohadiprojo,S. Prawirokusumodan S. Lendosoekodjo. 1998. Ilmu Makanan Ternak Dasar. Gadjah Mada University Press.Yogyakarta. 